\title{
Polyethylene Glycol-induced Uptake of Bacteria into Yeast Protoplasts
}

\author{
Takashi Yamada and Kenji SAKaguchI \\ Mitsubishi-Kasei Institute of Life Sciences, \\ 11 Minamiooya, Machida-shi, Tokyo 194, Japan
}

Received April 13, 1981

\begin{abstract}
Cells of the nitrogen-fixing bacterium Azotobacter vinelandii and the unicellular cyanobacterium Anacystis nidulans were introduced into protoplasts of Saccharomyces cerevisiae by the polyethylene glycol (PEG) method. Factors influencing the uptake frequency were examined, and experimental conditions were established for maximizing the uptake frequency. Under optimal conditions, each protoplast took-up a few bacterial cells. Electron-microscopic studies showed the localization of integrated bacterial cells in membrane-bound vesicles of the cytoplasm or large vacuoles. The protoplasts at the intermediate stages of uptake revealed two major mechanisms of uptake: (a) "endocytosis" by a single protoplast and (b) "cell fusion" between two or more protoplasts. Some bacterial cells disintegrated during the subsequent incubation period through a heterophagy-like process.
\end{abstract}

Since the molecular cloning technique has recently allowed successful transfer of nitrogen-fixation (nif) genes among several bacterial genera, ${ }^{1 \sim 6)}$ it may be considered to be possible to introduce nif genes into eukaryotic cells such as plants with viruses or plasmids. Even if this is done, there are some barriers before the actual expression of nif genes takes place in eukaryotes; for example, nitrogenase requires protection from oxygen and a supply of much ATP. ${ }^{\text {?) }}$

All naturally occurring eukaryotic nitrogenfixing systems are endosymbioses in which host cells contain nitrogen-fixing prokaryotes in cytoplasmic vesicles such as in the cases of the legume-Rhizobium system, ${ }^{8,9}$ Protozoacyanobacteria systems and cyanelles. ${ }^{10}$ Therefore, the incorporation into eukaryotic cells of microorganisms capable of aerobic nitrogen-fixation as endosymbionts could be a possible means of extending nitrogen-fixation to eukaryotes.

It has been shown that polyethylene glycol treatment of plant and fungal protoplasts induces, as well as cell-to-cell fusion, uptake of external materials. Plant and fungal protoplasts were shown to take up organelles ${ }^{11,12)}$ and microorganisms. ${ }^{13 \sim 17)}$ However, the uptake mechanisms, the cellular localization of symbionts, and the fate of these artificially forced associations have never been fully investigated. Only Giles and Whitehead ${ }^{15)}$ reported an association that was stable for a long period. They intorduced cells of an aerobic nitrogen-fixing bacterium, Azotobacter vinelandii, into fungal protoplasts (Rhizopogon sp.). The nitrogen-fixation activity of the association was observed for up to 138 days.

In this work, we introduced nitrogen-fixing cells of $A$. vinelandii and photosynthetic cells of $A$. nidulans into yeast protoplasts by the PEG method, and examined factors affecting the uptake frequency, mechanisms of the uptake event, and the fate of the artificial association.

\section{MATERIALS AND METHODS}

Microorganisms and cultures. The heterothallic triploid wild type strain, Saccharomyces cerevisiae A71, ${ }^{18}$ was used as a host. Cells were grown at $30^{\circ} \mathrm{C}$ with shaking in a medium containing $1 \%$ yeast extract, $2 \%$ peptone, and $2 \%$ glucose (YPG). Azotobacter vinelandii NCIB8789 (wild 
type) was grown at $30^{\circ} \mathrm{C}$ with shaking in a modified Burk's nitrogen-free medium ${ }^{19}$ containing: $\mathrm{KH}_{2} \mathrm{PO}_{4}$, $0.2 \mathrm{~g} ; \mathrm{K}_{2} \mathrm{HPO}_{4}, 0.8 \mathrm{~g} ; \mathrm{MgSO}_{4} \cdot 7 \mathrm{H}_{2} \mathrm{O}, 0.2 \mathrm{~g} ; \mathrm{CaCl}_{2} \cdot 2 \mathrm{H}_{2} \mathrm{O}$, $0.09 \mathrm{~g}$; sucrose, $20 \mathrm{~g} ; 1 \mathrm{ml}$ of $\mathrm{Fe}-\mathrm{Mo}$ solution $(1 \%$ $\mathrm{FeSO}_{4} \cdot 7 \mathrm{H}_{2} \mathrm{O}$ and $\left.0.1 \% \mathrm{~K}_{2} \mathrm{MoO}_{4}\right)$; in $\mathrm{H}_{2} \mathrm{O}, 1,000 \mathrm{ml}$. The growth was measured with a Klett-Summerson photoelectric colorimeter. Exponentially growing cells of $A$. vinelandii were labeled by addition of a uniformly labeled ${ }^{14} \mathrm{C}$-L-amino acid mixture (New England Nuclear) at $0.5 \sim 1.0 \mu \mathrm{Ci}$ per $\mathrm{ml}$ of the growth medium for $2 \sim 4 \mathrm{hr}$. Under the growth conditions described, the incorporation of the label was approximately $3 \times 10^{3} \mathrm{cpm}$ per $10^{8}$ cells. The cyanobacterium, Anacystis nidulans M-6, was obtained from the Institute of Applied Microbiology, University of Tokyo. The cells were grown at $\mathrm{pH} 8.0$ in a modified Detmer medium (MDM) containing per liter: $\mathrm{KNO}_{3}, 1.0 \mathrm{~g} ; \mathrm{MgSO}_{4} \cdot 7 \mathrm{H}_{2} \mathrm{O}, 0.25 \mathrm{~g} ; \mathrm{K}_{2} \mathrm{HPO}_{4}, 0.25 \mathrm{~g}$; $\mathrm{NaCl}, 0.1 \mathrm{~g} ; \mathrm{CaCl}_{2} \cdot \mathrm{H}_{2} \mathrm{O}, 0.01 \mathrm{~g} ; \mathrm{I} \mathrm{ml}$ of Fe-solution $(0.2 \%$ $\mathrm{FeSO}_{4} \cdot 7 \mathrm{H}_{2} \mathrm{O}$ ); $1 \mathrm{ml}$ of $\mathrm{A}_{5}$ solution. ${ }^{20)}$ Cultures were incubated at $30^{\circ} \mathrm{C}$ under continuous illumination from daylight fluorescent lamps (ca. 3,000 lux).

Preparation of yeast protoplasts. Yeast cells in the late exponential phase of growth were harvested, washed, and suspended in a protoplast-forming medium (PFM) con-

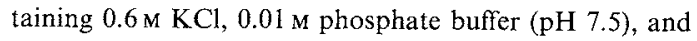
$0.6 \mathrm{mg} / \mathrm{ml}$ Zymolyase 5,000 (Kirin Brewery Co., Japan). ${ }^{21 \text { ) }}$ The cells were incubated at $30^{\circ} \mathrm{C}$ for $2 \mathrm{hr}$ with gentle shaking. Prepared protoplasts were collected by centrifugation at $1,000 \times g$ for $10 \mathrm{~min}$, washed, and suspended in $0.6 \mathrm{M} \mathrm{KCl}$. The number of protoplasts was determined with a hemacytometer.

PEG treatment. The standard procedure was as follows. To $1 \mathrm{ml}$ of a mixture of yeast protoplasts $\left(2 \times 10^{7}\right.$ cells $)$ and bacterial cells (the labeled $A$. vinelandii, ca. $2 \times 10^{9}$ cells, $\left.6 \times 10^{4} \mathrm{cpm}\right), 0.5 \mathrm{ml}$ of aqueous $45 \%(\mathrm{w} / \mathrm{v})$ PEG 4,000 (Wako Pure Chemical Industries, Japan) solution containing $75 \mathrm{mM} \mathrm{CaCl}_{2}$ was added, and the mixture was incubated at $30^{\circ} \mathrm{C}$ for 20 to $30 \mathrm{~min}$. After centrifugation at $1,000 \times g$ for $15 \mathrm{~min}$, protoplasts were resuspended in $0.05 \mathrm{M}$ Tris- $\mathrm{HCl}$ buffer ( $\mathrm{pH} 8.0$ ) containing $20 \%$ sucrose, and incubated at $30^{\circ} \mathrm{C}$ for 1 to $2 \mathrm{hr}$. The protoplasts were then washed several times with the same buffer and collected on a Whatman GF/C filter by filtration. After drying, the filter was put in a scintillation vial containing $10 \mathrm{ml}$ of a toluene scintillator solution. The radioactivity was measured with a Beckman LS-250 scintillation counter. For electron microscopy, cells of $A$. nidulans were used instead of $A$. vinelandii as a symbiont because, unlike $A$. vinelandii, $A$. nidulans has electron microscopically distinguishable cellular structures such as the lamella structure of thylakoids.

Electron microscopy. Cells for transmission electron microscopic examination were fixed for $2 \mathrm{hr}$ at $4^{\circ} \mathrm{C}$ with $2 \%$ glutaraldehyde in $0.1 \mathrm{M}$ phosphate buffer ( $\mathrm{pH} 7.4$ ) containing $20 \%$ sucrose, post-fixed with $1 \% \mathrm{OsO}_{4}$ in the same buffer for $2 \mathrm{hr}$, dehydrated in a graded ethanolseries, transferred to QY-1 (n-butylglycidyl ether), and immersed in Epon. Thin sections were cut with a Sorvall MT-1 microtome, and stained successively with $2 \%$ uranylacetate for $30 \mathrm{~min}$ and a lead salts mixture ${ }^{22}$ for $5 \mathrm{~min}$. They were examined under a JEM-100B (JEOL) electron microscope at $80 \mathrm{kV}$. Cells for scanning electron microscopy were fixed and dehydrated in the same manner as for the transmission microscopy, suspended in acetone, and dried at room temperature. A small portion of the dried material was attached to a conductive stub and sputter-coated with gold and palladium in an Eiko JB-3 Ion Coater. Samples were examined under a JEM-100CX (JEOL) scanning electron microscope.

\section{RESULTS AND DISCUSSION}

\section{Factors influencing the uptake frequency}

Cells of $A$. vinelandii were taken up into yeast protoplasts on PEG treatment (Fig. 1). The degree of the uptake was estimated by counting the radioactivity of the ${ }^{14} \mathrm{C}$-labeled bacterial cells on a glass filter after the PEG treatment and the washings (see MATERIALS AND METHOds). Table I shows the radioactivity remaining after the washing of various combinations of yeast cells and PEG concentrations. The counts did not decrease anymore on successive washings or on digestion with lysozyme $(1 \mathrm{mg} / \mathrm{ml})$ at $30^{\circ} \mathrm{C}$ for $1 \mathrm{hr}$. Factors that influence the uptake frequency are listed in Table II. The maximal uptake, $2 \sim 3$ bacterial cells per protoplast, was obtained when yeast protoplasts were mixed with ca. 100 -fold bacterial cells, treated with $30 \%$ PEG 4,000 solution containing 50 to $60 \mathrm{~mm}$ $\mathrm{CaCl}_{2}$ at $30^{\circ} \mathrm{C}$ for $30 \mathrm{~min}$, and washed and incubated in $50 \mathrm{~mm}$ Tris- $\mathrm{HCl}(\mathrm{pH} 8.0)$ containing 50 to $60 \mathrm{mM} \mathrm{CaCl}$. With higher concentrations of $\mathrm{CaCl}_{2}$ in the PEG solution, lower concentrations of PEG were required for effective uptake (Fig. 2). The optimal conditions for the uptake were similar to those reported for fungal protoplast fusions, ${ }^{23,24)}$ which indicates some involvement of the membrane fusion mechanism in the uptake event. 


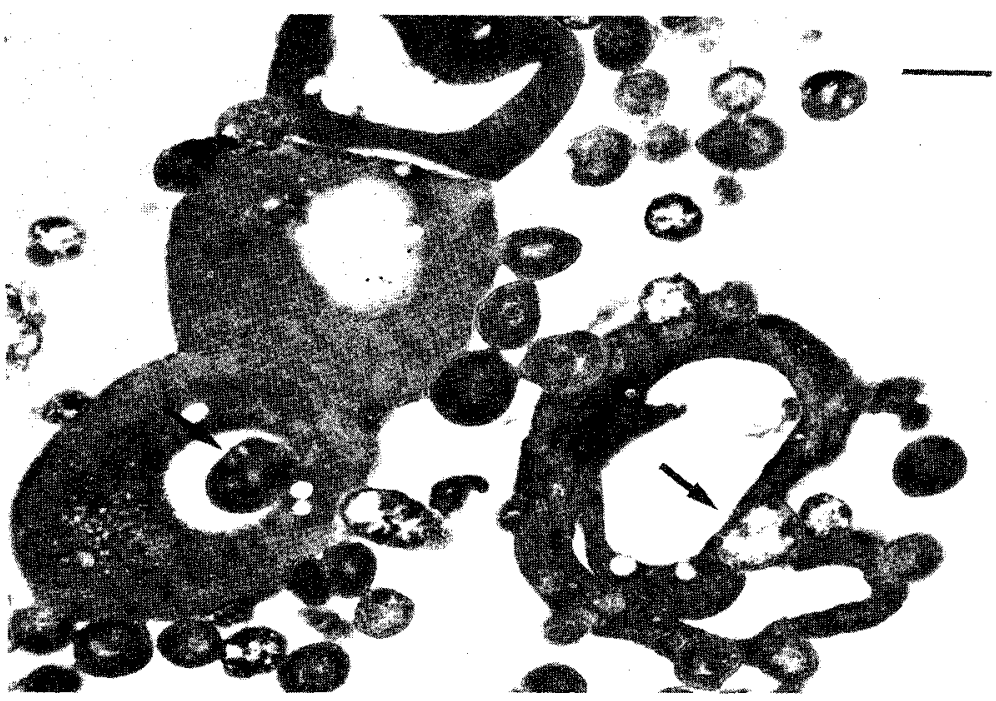

Frg. 1. Electron Micrograph Showing a Cell Aggregate of Yeast Protoplasts and Cells of A. vinelandii after PEG Treatment.

Bacterial cells were taken up into the yeast protoplasts (arrows). Bar marker represents $1.0 \mu \mathrm{m}$.

Table I. Uptake of ${ }^{14}$ C-Labeled Bacterial Cells by Yeast Protoplasts*

\begin{tabular}{lcc}
$\begin{array}{c}\text { Yeast cells } \\
\left(2 \times 10^{7}\right)\end{array}$ & $\begin{array}{c}\text { REG } \\
(\%)\end{array}$ & $\begin{array}{c}\text { Radioactivity } \\
\text { retained }(\mathrm{cpm})^{a}\end{array}$ \\
\hline None & 30 & $76 \pm 30$ \\
Whole cells & 30 & $368 \pm 85$ \\
Protoplasts & 30 & $1170 \pm 125$ \\
Protoplasts & $0^{b}$ & $163 \pm 40$ \\
\hline
\end{tabular}

* Protoplasts or whole cells were mixed with labeled cells of $A$, vinelandii $\left(2 \times 10^{9}\right.$ cells $)$ and treated with PEG solution containing $50 \mathrm{~mm} \mathrm{CaCl}_{2}$ at $20^{\circ} \mathrm{C}$ for $30 \mathrm{~min}$.

a Values from three experiments.

$b$ Protoplasts were treated with $0.6 \mathrm{M} \mathrm{KCl}$ solution containing $50 \mathrm{~mm} \mathrm{CaCl}$.

\section{Mechanisms of the uptake}

$A$. nidulans was used as a symbiont in cytological studies because $A$. vinelandii possesses less characteristic structures and is sometimes indistinguishable from the host cells (Fig. 1). A. nidulans possesses a photosynthetic lamellar structure of thylakoids which can be used as a marker for long time experiments.

Yeast protoplasts and cyanobacterial cells treated with PEG instantaneously formed
TABLE II. FaCtors AFFECTING THE UPTAKE FREQUENCY*

\begin{tabular}{|c|c|c|}
\hline Factors & & $\begin{array}{l}\text { Radioactivity retained } \\
(\% \text { of control })\end{array}$ \\
\hline \multirow[t]{4}{*}{ PEG, 4000} & $10(\%)$ & 24 \\
\hline & 20 & 75 \\
\hline & 30 & 100 \\
\hline & 40 & 101 \\
\hline \multirow[t]{4}{*}{$\mathrm{CaCl}_{2}$} & $20(\mathrm{~mm})$ & 48 \\
\hline & 40 & 75 \\
\hline & 60 & 100 \\
\hline & 80 & 100 \\
\hline \multirow[t]{3}{*}{ Temperature } & $20\left({ }^{\circ} \mathrm{C}\right)$ & 85 \\
\hline & 30 & 100 \\
\hline & 40 & 80 \\
\hline \multirow[t]{4}{*}{$\mathrm{pH}^{a}$} & 6.0 & 55 \\
\hline & 7.0 & 60 \\
\hline & 8.0 & 100 \\
\hline & 9.0 & 87 \\
\hline \multicolumn{3}{|c|}{ Cell ratio (Bacteria/Yeast) } \\
\hline & 1 & 0.1 \\
\hline & 10 & 6 \\
\hline & 100 & 100 \\
\hline & 1,000 & 72 \\
\hline
\end{tabular}

* The standard procedure (control experiment) is described in Materials and Methods.

a After the PEG treatment, cells were washed, resuspended and incubated in $0.05 \mathrm{M}$ Tris-Maleate buffer ( $\mathrm{pH} 6$ and 7 ) or $0.05 \mathrm{~m}$ Tris- $\mathrm{HCl}$ buffer $(\mathrm{pH} 7$, 8 and 9) containing $20 \%$ sucrose. 


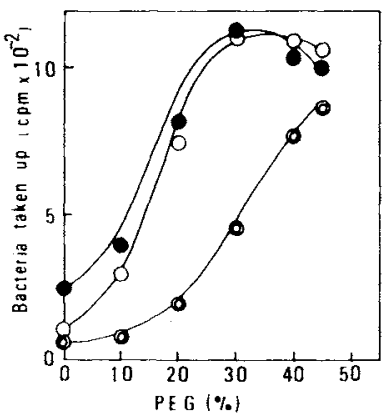

FIG. 2. Effects of Concentrations of PEG and $\mathrm{CaCl}_{2}$ on the Uptake of Labeled Bacterial Cells into Yeast Protoplasts.

PEG solutions of each concentration contained $10 \mathrm{~mm}$ (@), $50 \mathrm{~mm}(\mathrm{O})$, or $100 \mathrm{~mm}(\odot) \mathrm{CaCl}_{2}$.

large non-specific aggregates (Figs. 3A and $\mathrm{B}$ ). Cyanobacterial cells were in the aggregates and were taken up into yeast protoplasts through two mechanisms. In one mechanism, a cyanobacterial cell first adhered to the plasma membrane of a protoplast and formed a depression in the membrane (Fig. 3A). The plasmolysing effect of PEG then caused the depression to become a deep invagination containing the cell in the peripheral cytoplasm of the yeast protoplast (Figs. 4A and B). Subsequent sealing of the opening of the invagination by the fusion of the membrane resulted in the release of the cyanobacterial cell in the membrane bound vesicle into the cytoplasm of the protoplast (Figs. 4C, D, E, and F). The other mechanism of uptake was suggested by the electron micrographs shown in Fig. 5. In this case, the cyanobacteria were initially surrounded by two or more yeast protoplasts (Fig. 5A). The plasma membranes of the protoplasts surrounding the cyanobacterial cells subsequently fused with each other at the contact sites (Figs. 5B and C). After completion of the cell fusion, cyanobacterial cells were contained in membrane-bound vesicles within the cytoplasm of the yeast protoplasts (Fig. 5C). Figure 6 schematically shows these mechanisms.

The organisms taken up were localized in membrane-bound vesicles or sometimes in large vacuoles (Fig. 7). This is the case for most naturally occurring endosymbioses ${ }^{25)}$ as well as for experimentally established endosymbioses as reported by Ahn and Jeon ${ }^{26)}$ and Jolley and Smith. ${ }^{27)}$ Enclosure by the host membrane might be a prerequisite for the symbiont to establish a stable association. ${ }^{25}$ )

\section{Stability of the association}

Meeks et al. ${ }^{17)}$ observed for the association between tobacco protoplasts and a cyanobacterium, Anabaena variabilis, that most of the protoplasts expelled the cyanobacterium and simultaneously disintegrated. Apparent ejection, however, was not observed for the yeastbacteria system, although some protoplasts were disrupted during the incubation period. The bacterial cells taken up may eventually be digested by hydrolyzing enzymes through a heterophagy-like process since several enzyme activities such as those of peptidases, proteases, RNase(s), and phosphatases are reported to be located in the vacuoles of yeast cells. ${ }^{28)}$ In fact, the possibility of heterophagy was suggested by Fig. 8. It shows a yeast protoplast with cells of $A$. nidulans incubated for $24 \mathrm{hr}$ at $30^{\circ} \mathrm{C}$ after PEG treatment. Two of three bacterial-cells in the protoplast are considerably degraded. Some of the endocytotic vacuoles derived from the invagination of the plasma membrane might be modified to acquire the lysosomal function; this can be attained through the fusion of vacuoles during the yeast growth cycle. ${ }^{29)}$ The rapid disappearance of labeled bacteria in the growth medium might be caused by the heterophagy process and/or selective rupturing of the protoplasts preceding the subsequent growth.

So far, we have failed in forming a stable nitrogen-fixing association between Saccharomyces and Azotobacter. In order to establish a stable association, there would be, in addition to the digestion, at least three other conditions for microorganisms to satisfy after the entry into a host cell: (1) a supply of nutrient and growth factors from the host, (2) cell division in harmony with that of the host, and (3) harmlessness to the host.

This paper concerns the uptake stage of the 

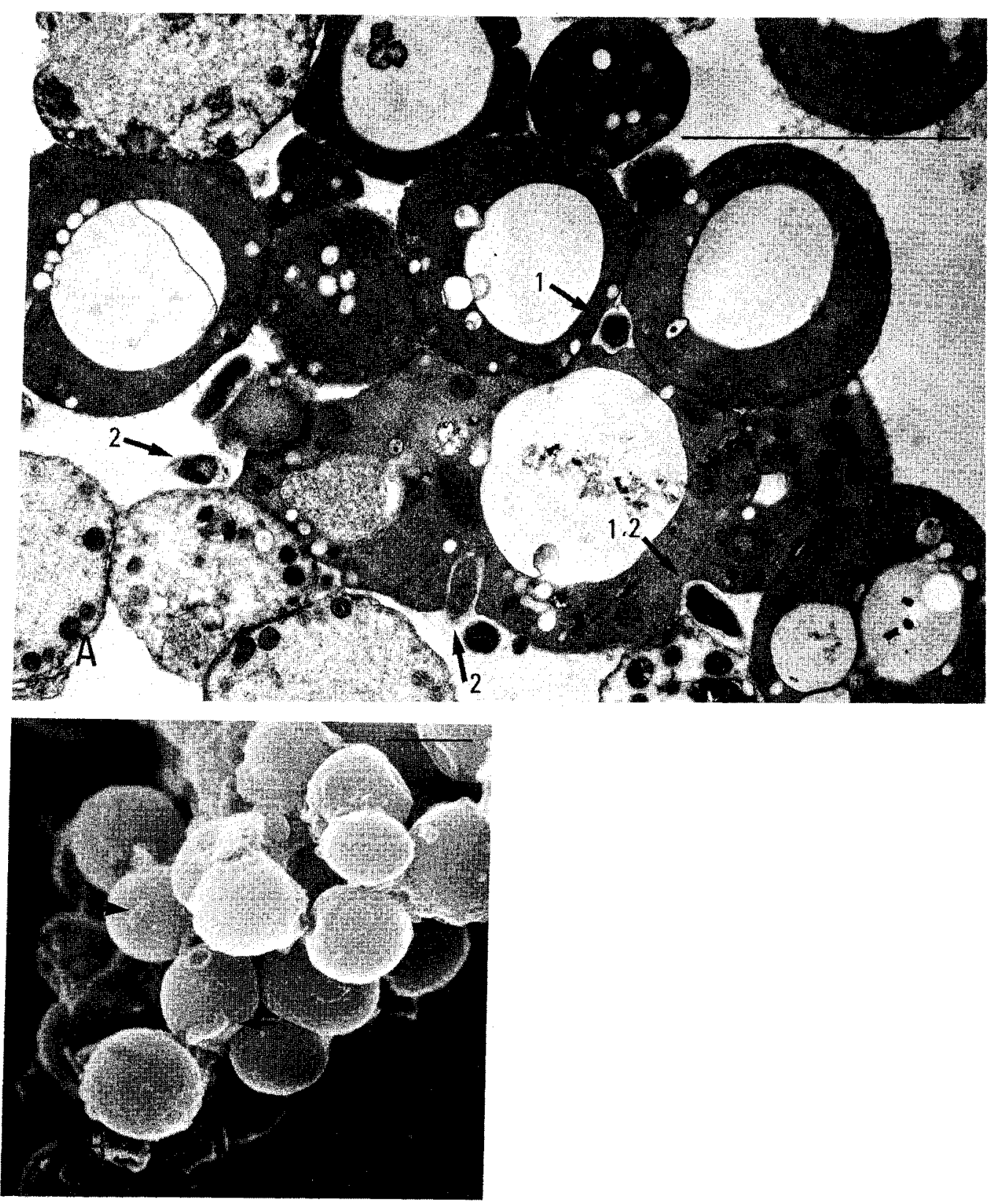

FIG. 3. Electron Micrographs of a Large Non-specific Cell Aggregate of Yeast Protoplasts and Cyanobacterial Cells (A. nidulans) Formed by PEG-Treatment.

(A) A thin section of the aggregate. The cyanobacterial cells are enclosed within yeast protoplasts (arrow I) or sticking in invaginations of the protoplast membranes (arrow 2). Bar marker represents $10 \mu \mathrm{m}$. (B) Scanning electron micrograph of the aggregate. The cyanobacterial cells are indicated by arrows. Bar marker represents $10 \mu \mathrm{m}$. 

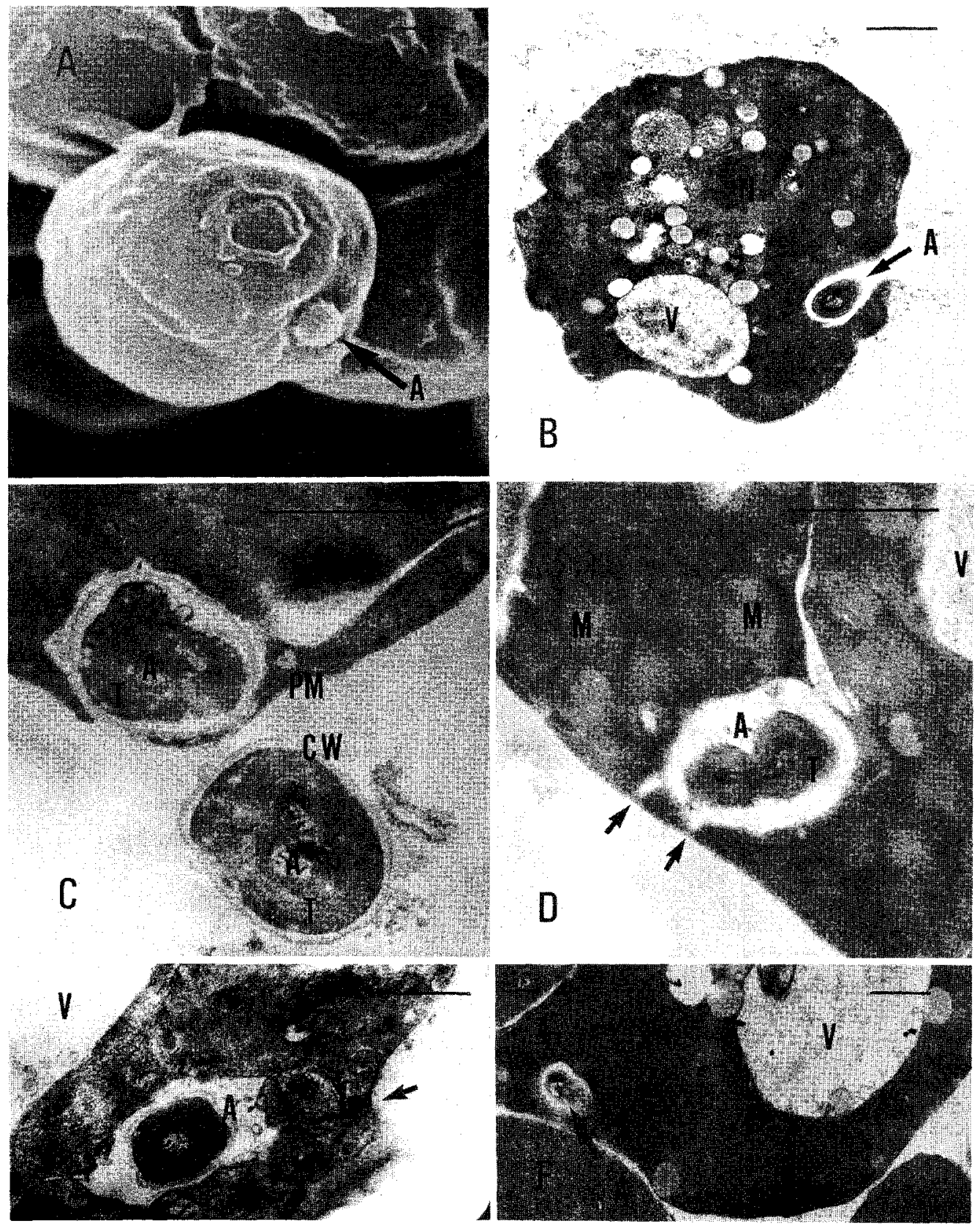

FIG. 4. Electron Micrographs Showing Several Stages of Uptake of the Cyanobacterial Cells (A. nidulans) by Yeast Protoplasts.

The cyanobacterial cell initially adhering to the surface of the yeast protoplast enters deeply into the invagination of the protoplast (A and B). Subsequent sealing of the opening of the invagination (C) by fusion of the membrane (arrows in $\mathrm{D}$ and $\mathrm{E}$ ) releases a membrane-bound vesicle enclosing the cyanobacterial cell into the cytoplasm of the protoplast (F). A; Anacystis nidulans cell, CW; cell wall, M; mitochondrion, N; nucleus, PM; plasma membrane, T; thylakoid of the cyanobacterial cell, V; vacuole. Bar marker represents $1.0 \mu \mathrm{m}$. 

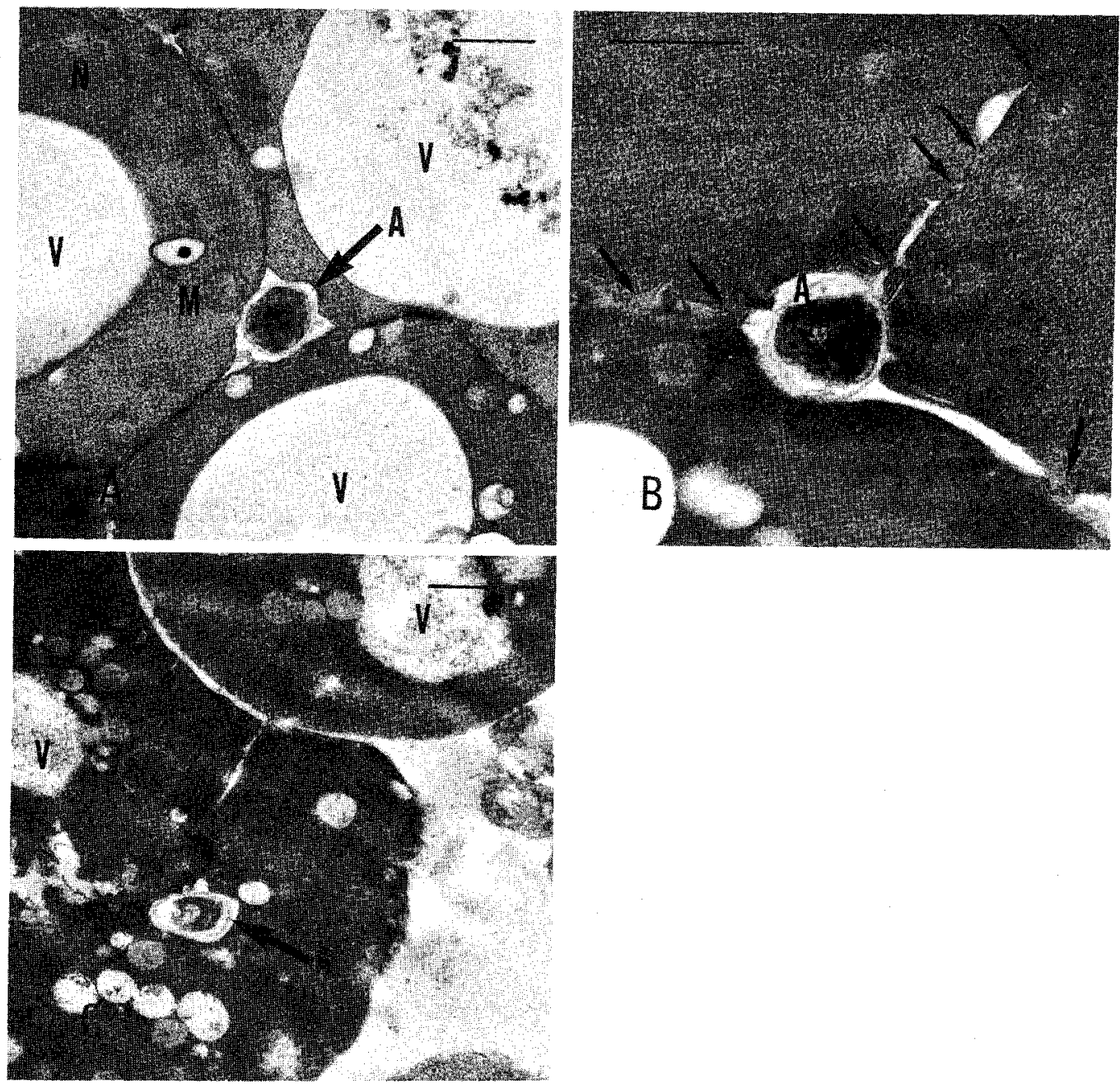

Fig. 5. Thin Sections Indicating Another Mechanism of Uptake by Yeast Protoplasts.

(A) A cyanobacterial cell is surrounded by three yeast protoplasts. Subsequently, the plasma membranes of the protoplasts surrounding the cyanobacterial cell fuse with each other at the contact sites indicated by arrows (B), (C) After the fusion, the cyanobacterial cell is released in a cytoplasmic vesicle. Abbreviations used are the same as in Fig. 4. Bar marker represents $1.0 \mu \mathrm{m}$.

establishment of an association. The detailed fate of the association and several influencing factors for establishing a stable system are now under investigation.

\section{REFERENCES}

1) R. Dixon, F. C. Cannon and A. Kondrosi, Nature, 260, 268 (1976)

2) F. C. Cannon and J. R. Postgate, Nature, 260, 271 (1976).

3) M. L. Skotnicki and B. G. Rolfe, J. Bacteriol., 133,
$518(1978)$

4) J. Stanley and K. L. Dunican, Molec. Gen. Genet, 174, 211 (1979).

5) A. Pühler, H. J. Burkhardt and W. Klepp, Molec. Gen. Genet., 176, 17 (1979).

6) K. Krishnapillai and J. R. Postgate, Arch. Microbiol., 127, $115(1980)$.

7) M. J. Dilworth, Ann. Rev. Plant Physiol., 25, 81 (1974).

8) M. R. Davey, E. C. Cocking and E. Bush, Nature, 244, 460 (1973).

9) J. E. Beringer, N. Brewein, A. W. B. Johnston, H. M. Schulman and D. A. Hopwood, Proc. Roy. Soc. 
(1)
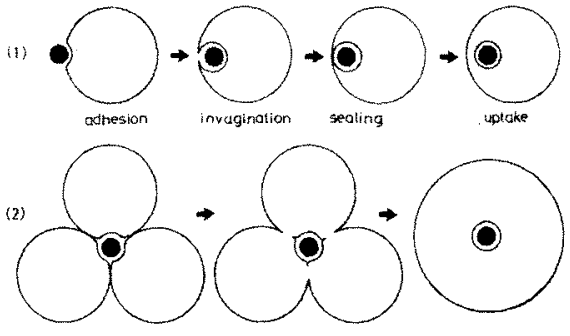

sutrounding

cell tusion

uptake

FIG. 6. Diagrammatic Representation of the Two Mechanisms of Uptake of Cyanobacterial Cells $(A$. nidulans) by Yeast Protoplasts.

The large circle and the small black circle represent the yeast protoplast and the cyanobacterial cell, respectively.

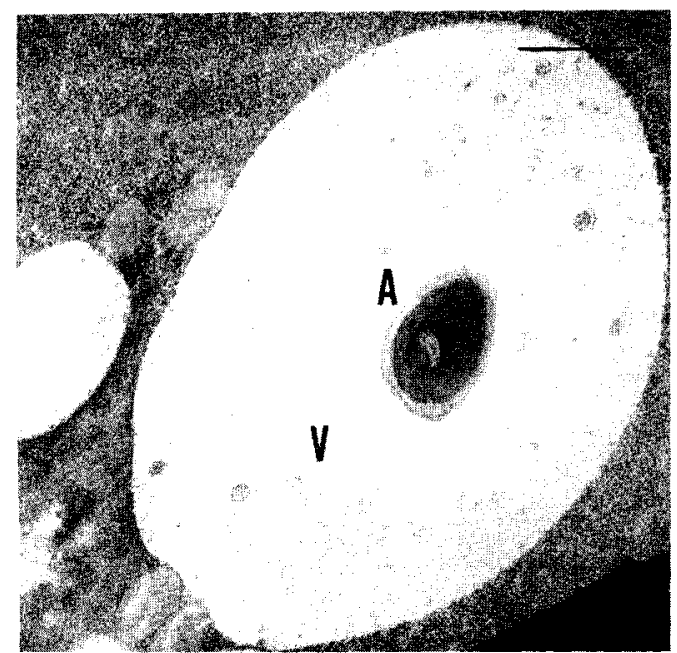

FIG. 7. A Thin Section Showing a Yeast Protoplast Containing a Cyanobacterial Cell in the Large Vacuole. Bar marker represents $1.0 \mu \mathrm{m}$.

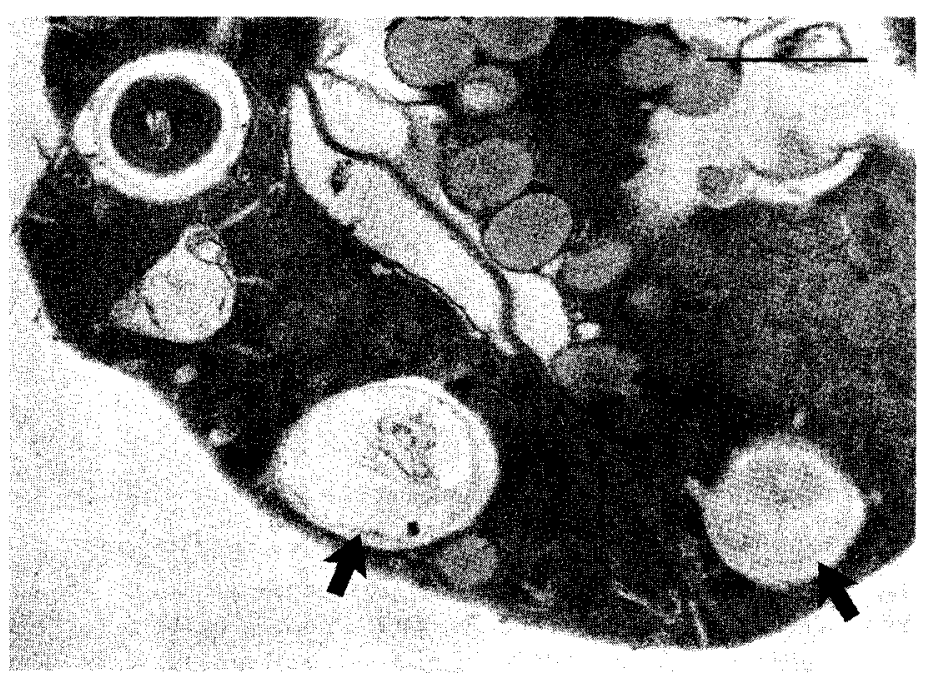

FIG. 8. Electron Micrograph Showing a Yeast Protoplast Containing Cyanobacterial Cells; after Incubation.

Two of three cyanobacterial cells in the cytoplasmic vesicles are disintegrated (arrows). Cell wall materials and the cytoplasmic debris can be seen. Bar marker represents I $\mu \mathrm{m}$.

Lond. B, 204, 219 (1979).

10) B. A. Whitton, "The Biology of Blue-green Algae," ed. by N. G. Carr and B. A. Whitton, Blackwell Scientific Publications, Oxford, London, Edinburgh, Melbourne, 1973, p. 415.

11) H. T. Bonnett and T. Ericksson, Planta, 120, 71 (1974).

12) I. K. Vasil and K. L. Giles, Science, 190, 680 (1975).

13) M. R. Davey and J. B. Power, Plant Sci. Lett., 5, 269
(1975).

14) A. C. Burgoon and P. J. Bottino, J. Heredity, 67, 223 (1976).

15) K. L. Giles and H. Whitehead, Science, 193, 1125 (1976).

16) A. C. Burgoon and P. J. Bottino, "Genetic Engineering for Nitrogen Fixation," ed. by A. Hallaender, R. H. Burris, P. R. Day, R. W. F. Hardy, D. R. Helinsky, M. R. Lamborg, L. Owens, 
and R. S. Valentine, Plenum Press, New York, London, 1977, p. 213.

17) J. C. Meeks, R. L. Malmberg and P. C. Wolk, Planta, 139, 55 (1978).

18) N. Gunge and Y. Nakatomi, Genetics, 70, 41 (1972).

19) G. W. Strandberg and P. W. Wilson, Gan. J. Microbiol., 14, 25 (1968).

20) O. Holm-Hansen, G. L. Gerloff and F. Skoog, Physiol. Plantarum, 7, 665 (1954).

21) K. Kitamura and Y. Yamanoto, Arch. Biochem. Biophys., 153, 403 (1972).

22) G. Millonig, J. Biophys. Biochem. Cytol., 11, 736 (1963).
23) L. Ferenczy, F. Kevei, F. Frank's and I. Rojik, Experientia, 32, 1156 (1976).

24) J. F. Peberdy, Ann. Rev. Microbiol., 33, 21 (1979).

$25)$ D. C. Smith, Proc. Roy. Soc. Lond. B., 204, 115 (1979).

26) T. I. Ahn and K. W. Jeon, J. Cell Physiol., 98, 49 (1979).

27) E. Jolley and D. C. Smith, Proc. Roy. Soc. Lond. B., 207, 311 (1980).

28) A. Wiemken, M. Schellenberg and K. Urech, Arch. Microbiol., 123, 23 (1979).

29) A. Wiemken, Ph. Matile and H. Moor, Arch. Microbiol., 70, 89 (1970). 